\title{
Hospitality to difference: LGBT, religious education and the Catholic school
}

\author{
Roisín Coll ${ }^{1}$ (D)
}

Accepted: 6 November 2020 / Published online: 21 November 2020

(c) The Author(s) 2020

\begin{abstract}
There has been a rise in claims of LGBTI youth in schools generally across the UK with a surge in young people self-identifying. This is a 'theme' or 'matter' or 'question' that has been insufficiently ventilated in relation to the Catholic school. It is shrouded in inhibition, confusion, evasion or fear. Burying our heads in the sand is not helping us move forward and there is a potential political threat to the mission of Catholic schools from failing to engage. A key driver of this paper is the rapidly changing climate of opinion and activism around LGBTI experiences in schools and society. From an essentially rights based perspective, and supported by powerful equality legislation, people are campaigning vigorously through formal and informal groups for what they perceive as a redress of longstanding exclusion and discrimination. The concern in particular for LGBTI rights and recognition for under $18 \mathrm{~s}$ has inevitably drawn schools into these national debates. Three narratives are worthy of discussion around this theme and are inextricably linked: the legal, theological and pastoral narratives. This paper will consider these and suggest the impact that developments are having on the Catholic school sector, and in particular, the teaching of Religious education.
\end{abstract}

Keywords Hospitality · LGBT · Religious Education · Otherness · Dialogue

\section{Introduction}

This paper is about how Catholic schools respond to children and young adults, who identify as LGBT, (Lesbian, Gay, Bisexual and Transgender) and the impact that this has on the teaching of Religious Education (RE) in Catholic schools. There is a spectrum of opinion that exists on the matter from within the Catholic community. For example, for some a paper concerned with this matter will be a welcome addition to the existing discourse (or perhaps lack of it) that considers Religious Education in the Catholic setting. It is recognised that others committed to Catholic Education will be uncomfortable that it is being raised as a point of discussion and may have strong opposition even to the terminology to which is referred. However, regardless of individuals' position on this emotive topic,

\section{Roisín Coll}

Roisin.coll@glasgow.ac.uk

1 University of Glasgow, Glasgow, UK 
it is considered timely and appropriate to address it and the aim is to stimulate additional discourse.

Three discourses impinge directly on this paper and they are inextricably linked: the legal/political, the theological and the pastoral. All three will be considered and their impact on the Catholic school sector discussed, in particular, the teaching of Religious Education by the light of them. The paper, therefore, will be in three parts. First of all, to examine briefly the current climate in terms of the LGBT movement and to present a picture of the rapidly changing climate of opinion and activism that currently exists in society giving an example from the Scottish context.

The Church context will be addressed next. However rather than exploring in detail what the Church teaches-which is assumed is known - the paper will look at the apparent dichotomy that exists between the Church's moral position and its pastoral position and how this dichotomy affects Catholic schools. There are many complexities around this, including use of language and the range of opinion that exists from within the Church and Catholic community. Drawing on a burgeoning of interest in theological, philosophical and anthropological literature in the concept of 'hospitality', this will be the focus of this section along with the importance of 'otherness', both of which have a locus in this context.

Finally, in relation to the teaching of Religious Education in Catholic schools, gaps will be identified and suggestions made as to what is required to support teachers and leaders of Catholic schools to ensure that they can continue to do their job as confident authentic and authoritative Catholic educators in the midst of great social and cultural change (Coll 2009).

Interest in this field of study has stemmed from a number of key factors. In Scotland's education system-which is very different from the English system and elsewhere in the UK owing to Education being a devolved matter-all faith schools (with three exceptions) are Roman Catholic, but these schools are entirely part of the state system, fully funded by the state, including all Catholic teachers being employed by the state. However, enshrined in law (1918 Education (Scotland) Act), the Catholic Church retains control over the RE curriculum that is taught within Scottish Catholic schools and the approval of all those teaching in these schools in terms of their belief and character. These two factors have safeguarded the strong Catholic religious identity of the schools for over 100 years.

Being a minority faith group within the country, yet occupying such a prominent position in terms of distinctive educational provision, there have been significant tensions regarding the existence of Catholic schools in Scotland and strong opposition from sections of the wider Scottish community claiming they are divisive, indoctrinate children, breed sectarianism and contribute to the toxic undercurrent of religious bigotry that still exists in the country today, similar to that experienced in the North of Ireland (see for example, Bruce 2001; McKinney 2008, 2015). Of course, there have been numerous studies on this last 'phenomenon', which is very particular to this part of the world since, as we know, Catholic schools exist harmoniously with other schools elsewhere across the globe. Unsurprisingly not one piece of research has confirmed any of these extravagant claims. Regardless, those involved in Catholic education (see, for example, Conroy 2001) have, over the last three or four decades, had to be in a position to articulate clearly and confidently the value of this unique school system to the country as a whole: something which has been very efficaciously done and accepted and endorsed by the Scottish executive authorities (The Scottish Government 2018).

However, in recent years, the threat to the existence of Catholic schools in Scotland has somewhat altered. While there will continue to be the fight to end Catholic school provision in Scotland on the grounds of religious segregation, a newer narrative has emerged 
from the anti-Catholic school proponents which they believe strengthens their cause immeasurably and this links directly to the Catholic Church's perceived moral stance on matters pertaining to people who identify as LGBT, and how this stance is presented and taught in Catholic schools. As is the case elsewhere in the world, there has been a rise in claims of people identifying as LGBT generally throughout Scotland with a surge in young people self-identifying in accordance with this lexicon (Office for National Statistics 2019). It is a 'theme' or 'matter' or 'question' that has, in many countries, been insufficiently ventilated in relation to the Catholic school. It is often shrouded in inhibition, confusion, evasion or fear. Burying heads in the sand does not help move forward and there is a potential political threat to the mission of Catholic schools from failing to properly engage with it, particularly in countries such as Scotland where our Catholic schools are part of the state sector and expected to conform to all national regulations pertaining to equality and diversity (Education Scotland 2017).

This has exercised the attention of many and it is considered a necessity to engage and become academically and professionally informed in this field. Perhaps the underlying reason for interest in this area may be described as questionable since it has emerged from a defensive position and in response to a rapidly changing climate of secular opinion on the matter. Regardless, this paper aims to enrich awareness of a matter which often exists in inchoate form in the minds of many Catholic school leaders and religious educators, as well as wider society, and in the process create a much-needed space for better informed and thoughtful reflection on the matter.

\section{Part 1: LGBT activism}

In the past 30-40 years, there have been significant advances toward greater equality for sexual minorities with landmark changes in how both governments and democratic societies treat members of the lesbian, gay, bisexual, and transgender (LGBT) community across the world (Ghosh 2020). From an essentially rights-based perspective, and supported by powerful equality legislation, people are campaigning vigorously through formal and informal groups for what they perceive as a redress of longstanding exclusion and discrimination. Some very recent studies (see for example Tadlock and Glick 2019; Siegel 2019; and Page 2019) have demonstrated the rapid growth and ongoing momentum of the LGBT movement internationally, revealing its current youth and vitality. Indeed, the increase in scholarly research on LGBT over the past few decades parallels societal changes regarding increased support for LGBT people more generally. Tadlock and Glick (2019) who focus their studies on North America, Australia and Mexico explain that,

'changes over the years allow scholars to investigate topics such as how the LGBT movement compares to other social movements, how various sexual and gender minority communities have been incorporated into the larger movement, and how movement groups have utilised various strategies in pursuit of movement goals' (p1).

Equal treatment for members of the lesbian, gay, bisexual, and transgender (LGBT) community has improved at a rapid pace around the world since the gay rights movement first rose up in the 1970s to become a global force for change. This has impacted on civil society as a more or less continuous pattern of social and attitudinal transformation. It includes high profile campaigns for gay rights in the armed forces; equal 
treatment in the workplace; gender neutral facilities; recognition and support for those undergoing gender reassignment; controversial lobbying for pronoun regulation. In recent years, the boundaries of these movements have begun to extend chronologically and specially into zones where their presence was previously much less visible or accepted.

With important regional exceptions, Seigel (2019) highlights how laws criminalizing same-sex sexual relations have been abolished in multiple countries and same-sex couples are now able to construct their own families and in many advanced industrialized countries are able legally to adopt or enter into formal surrogacy arrangements. Public acceptance of homosexuality, even in some non-Western countries, has also increased dramatically (Siegel 2019, p. 1).

A comparison of the varying degrees to which the LGBT movement has grown across a range of countries in the developed world highlights some of the factors that have influenced and contributed to their development. For example, it has been recognised that the LGBT movement in Australia has seen a slower progression than in Canada or the United States, in part because it is argued that Australian social rights movements have not historically been as active as in other countries. Tadlock and Glick (2019) suggest that Australian social rights movements have come to consciousness more from a global than a domestic narrative. In Mexico, it is claimed that a stronger attachment to identification with religion has resulted in slower growth and vitality of LGBT movements despite having better electoral and policy successes, which they attribute to the legacy of historic revolutions and cultural commitments to emancipation (ibid).

It has also been argued that the rapid growth and impact of the LGBT rights based movement on policy and legislation, particularly in Western culture, has arisen as a result of an exceptionally successful strategic vision where,

'networks of activists at the national and international levels have provided the initiative, know-how, and political pressure to motivated politicians to influence both international rules and national rules' (Ayoub, 2016).

Indeed, this has been the narrative in Scotland where it is unlawful to discriminate against anyone on the grounds of any of nine named 'characteristics'. These characteristics that are protected by the Equality Act 2010 are:

- age

- disability

- gender reassignment

- marriage or civil partnership (in employment only)

- pregnancy and maternity

- race

- religion or belief

- $\operatorname{sex}$

- sexual orientation

Four of these have a specific resonance for those belonging to the LGBT community. Scotland is a country that is proud of its LGBT- inclusive record, which is evident from the Scottish Government's website. The opening paragraphs state:

'Scotland is considered one of the most progressive countries in Europe in terms of lesbian, gay, bisexual, transgender and intersex (LGBTI) equality.' 
The website https://www.gov.scot/policies/lgbti/ includes a list of accolades, including that of being recognised by the European Region of the International Lesbian, Gay, Bisexual, Trans and Intersex Association (ILGA Europe) as the most inclusive country for LGBTI equality and human rights legislation, meeting $92 \%$ of its 48 criteria.

This reputation, of course, has a powerful impact on the Scottish school system. For example, an LGBT lobby group in Scotland called Time for Inclusive Education (TIE) had their efforts rewarded when 50\% of the Members of Scottish Parliament agreed to offer support for their campaign to have, among other things, mandatory LGBT material taught in all schools in Scotland. They achieved this in a very short period, which resulted in the Scottish Government 2018 responding by establishing an Inclusive Education Working Party to consider the different proposals offered by TIE. These included mandatory inclusive LGBT content in teacher training programmes and in the national curriculum taught in all schools in Scotland, which of course includes Catholic schools.

The Catholic Church responded to the initiative by having strong representation on the working party and sub working parties. It was important for those lobbying for the TIE campaign that any agreed outcome would be implemented in all state schools in Scotland, that is, including Catholic schools.

The Church representatives responded by entering into 'genuine dialogue' but throughout the conversations stated that to reach agreement, what was being proposed had to work for the Catholic sector, therefore consideration had to be given to the Catholic Church's position on such matters since Church schools were also a part of the state system. From this basic point of principle, agreement was reached on what could therefore be proposed to the Scottish government. The Church was in a strong position throughout these debates and was treated as an equal voice in the whole process.

The Church's position on the wider LGBT debate, through the work of the Scottish Catholic Education Service (SCES), has fundamentally been about proportionality in terms of how much time, effort and resource is spent on consideration of inclusive education and LGBT matters. As previously stated, there are nine protected characteristics and those such as Race and Disability do not receive anywhere near the same attention. It is also an important point that the Equalities Act in the UK does not prescribe the content of the curriculum even if it sets the parameters. The act's main concern is with the how.

The Church in Scotland has chosen to engage with the LGBT lobby groups around education, such as TIE, despite some significant internal opposition. It could be argued that it needs to do this because it has to respond to the legal position set by the equalities act and the narrative that surrounds it. The Church was acutely aware of the momentum the LGBT movement was enjoying and anticipated this development. It is argued here that its proactivity resulted in it being 'ahead of the curve', since it was prepared to respond to the challenge in a meaningful way, and at policy level, and this was taken seriously through being given an equal voice in the discussions. It had also produced its own inclusive and equality education materials for use by teachers and staff development sessions for Catholic teachers in Catholic schools (SCES 2018).

What is not discussed here or judgment cast on the Church's position on the detail of this lobby group's proposals. This is not the point being made. What is of note, however, is the manner in which being ready, available and willing to enter into dialogue at a political level, and from the very start of the conversation, was critical in ensuring the Church had a voice. It was not reacting to policy which would affect, among other things, what is taught in schools, rather it was influencing its direction. Of course, the Church had a place at this table and was invited to participate since Catholic schools are part of the state system in Scotland and the Church retains legal jurisdiction over the content of the RE curriculum 
in its schools. In many other countries this is not the case and so the Church would not be afforded the same opportunity. But had the Church chosen not to engage, (which it could have done and has done in many countries with regard to similar political initiatives) then the outcome of this political working party could have been significantly different.

It is claimed here, then, that dialogue is paramount.

A recent issue of the Journal for Catholic Education is devoted to 'The Challenges and Opportunities of Including the LGBTQ Community in Catholic Education' and the introductory paper by Hutching and Fisher highlights the need for such exposure since they recognise that 'LGBTQ people, whether students, parents, teachers, or administrators, exist in Catholic educational institutions' (Hutching and Fisher 2019, p. 3). Yet there has been a dearth of research on the wider topic to help guide Catholic educators, who have had to balance adherence to the doctrine of the Catholic Church and the pastoral needs of those in their school community. They claim that when

'communities are not represented in research, when experiences are not identified and documented through a systematic approach to inquiry, a message of exclusionnot inclusion-is sent' (Hutching and Fisher 2019, p. 3).

From the outset of the journal issue the importance of dialogue is highlighted and explained for this context:

'For controversial topics, dialogue brings into focus the possibilities for genuine openness, listening, and transforming. Through the process of dialogue individuals and institutions can grow and better understand each other. Even when disagreement exists, the process of dialogue builds trust and greater connection' (ibid).

\section{Part 2: A Christian understanding of 'hospitality' and 'otherness'}

The next section of the paper will highlight a particular challenge that has arisen for the Church in the context of the Catholic school when considering the identity and growth of all children. The theological roots of a Christian understanding of 'hospitality' will then be explored, a concept undergoing a prolonged revival of interest today in both sacred and secular ethics (see for example Piquemal et al, 2019 and Razu 2019), and the importance of 'otherness' (for example, Mannarini et al 2020) which also has a firm locus within this conversation. First, it is important to draw our attention to language use. The following two paragraphs are taken from recent communication from the Catholic Church. The first is from a recent document on gender identity (Male and Female He created them) and the second from an address given by Pope Francis to teachers.

'The Catholic school should be an educating community in which the human person can express themself and grow in his or her humanity, in a process of relational dialogue, interacting in a constructive way, exercising tolerance, understanding different points of view and creating trust in an atmosphere of authentic harmony. Such a school is truly an "educating community, a place of differences living together in harmony. The school community is a place for encounter and promoting participation." (Congregation for Catholic Education 2018: para 40).

'Catholic schools should 'stimulate in pupils the openness to the other as a face, as a person, as a brother and sister to know and respect, with his or her history, merits and defects, riches and limits. The challenge is to cooperate to train young people to 
be open and interested in the reality that surrounds them, capable of care and tenderness.' (Francis 2018.)

The language used in both is arguably acceptable to the Church and those belonging to the LGBT community. Key words such as 'openness' 'interested' 'trust' 'encounter' 'respect' 'tolerance' feature-words that indicate a desire for two positions to find common ground. For example, 'trust' cannot exist in isolation. The very definition implies two different positions are occupied and 'trust' is an understanding and belief established between the two. 'Openness' is about the accessibility and transparency of different positions alongside a desire to engage. 'Respect' implies affirmation of the other as a result of recognition of their humanity.

In this context, and in these two examples cited, it is argued that the use of language here is helpful. However, this is not always the case with Church documentation, a view shared by senior Church leaders. For example Cardinal Joe Tobin, Archbishop of Newark was asked on US national television 'how can you welcome people that you call 'intrinsically disordered'?' referring to language used in the Catechism in relation to homosexuality. Responding, Tobin says, 'I don't call them intrinsically disordered. That is very unfortunate language. Let's hope that eventually that language is a little less hurtful' (Online, April 2018). He urged Church leaders to minister with more compassion since 'LGBT Catholics are as much a part of our Church as any other Catholic'. Indeed, it is important to acknowledge that despite the positive use of language in the example used above, the Church document on gender theory 'Male and Female He created them,' was not well received by many of the LGBT community since it is argued the discourse was considered to favour, unsurprisingly, a binary understanding of gender. There is a request for more dialogue with the Church in this area.

Appropriate language use is critical and highly symbolic of perspectives or positions. Pausing to remind ourselves of the Wittgensteinian argument that a word or even a sentence has meaning only as a result of the context or field in which it is written is worthwhile (Hacker 2009). In this highly emotive LGBT context, every word that is representative of the Church's position is considered, scrutinised, debated, accepted or refuted and so the 'meaning' that is intended has to be very carefully measured or interpretations of it can be, as we know, explosive. This is also of importance to key Church members such as the Religious Education teacher when educating children in schools about such matters. Many have echoed the comments of Tobin, that the catechism has such unhelpful language in relation to what the church teaches on same-sex attraction. Note that at times the conversation is about the unhelpful language rather than the unhelpful doctrine. These are two separate things but often the conversation about the doctrine or teaching cannot get started if the language used to discuss it is already creating a stumbling block.

In Catholic institutions there are employees who won't engage in any discussions about LGBT matters because they consider the use of the terminology as a secular construct and synonymous with condoning everything that the LGBT movement stands for. Others make a point of using secular terminology by way of demonstrating solidarity between a person of faith and the LGBT community. Language use is highly symbolic and meaning has to be managed exceptionally well if purposeful dialogue is desired.

As stated earlier, there is a burgeoning of interest in the concept of 'hospitality' in theological, philosophical and anthropological literature.

In his Encyclical Spe Salvi Benedict XIV writes: "This real life, towards which we try to reach out again and again, is linked to a lived union with a 'people' and, for each individual 
it can only be attained within this 'we'. It presupposes that we escape from the prison of our 'I', because only in the openness of this universal subject does our gaze open out to the source of joy, to love itself-to God" (para 14). This embraces the theme of hospitality and the importance of reaching out to the other and supporting community. Benedict goes on to warn against exclusivity as well as society's fear of involvement with the other.

In many of its documents, the Church has recognised the importance of understanding the concept of 'otherness' or being 'othered'. Again, in the Church document which has received significant attention, Male and Female He created them (Vatican 2019), which responds to contemporary Gender Theory, it states that the formation of one's identity is based on the principle of 'otherness'. It explains that the direct encounter between another "you" who is not me enables me to recognise the essence of the "I" who is me (para 27). Difference, it goes on to say is, in fact, a condition of all cognition, including cognition of one's identity.

'One's identity as a human person comes to authentic maturity to the extent that one opens up to others...' (para 33).

McGovern (2010) has explored this concept of otherness through a Christian lens and how it relates to an ethic of 'hospitality', focusing on its roots in scripture and paying particular attention to the person of Jesus.

'He who receives you, receives me; and he who receives me, receives him who sent me' (Matt 10:40).

Using scripture such as that above, McGovern demonstrates that the ethic of hospitality is powerfully present in much of Jesus' life and ministry. 'Jesus is portrayed in the New Testament as a wanderer without a home. From the very beginning of his life there is "no room...at the inn" (Luke 2:8)' (p73). Throughout his ministry, she explains how Jesus relies on the hospitality of others, for example Martha and Mary, Zaccheus, and then continues after his Resurrection, eg on the Road to Emmaus. Jesus remains a 'stranger' even to his disciples who do not really know him (John 21:12) and don't really understand him (John 3:4).

McGovern highlights how Hans Frei attempts to capture the elusive figure of 'Jesus the stranger':

Jesus is the archetypal man, or the pattern for authentic humanity. He is the stranger-as we all are-in this harsh and hostile universe... In just this wandering estrangement, Jesus is our embodiment or representative... As early as the moment of his conception and birth, it is symbolically the case that he has no place to lay his head $(2000,29)$.

She claims that this reflection on the humanity of Jesus is helpful to Christians and others since 'all readers and listeners are invited by the textual strategies of the New Testament to see something of themselves in the person of Jesus: their own loneliness, their isolation, and their personal search for a hospitable community'(p74). We welcome the stranger because we are strangers ourselves - and often to ourselves (ibid).

Matthew's Gospel demonstrates how hospitality and otherness are also key features of Jesus' teaching. There we find the parable of the sheep and goats (25:31). Those deemed righteous are those who were hospitable in feeding, clothing and welcoming the stranger which is portrayed by Matthew as the moral opportunity for the followers of Jesus to demonstrate their love of God. 
Interestingly, McGovern highlights that within the New Testament Jesus, as well as being the 'outsider' is also seen as the host, welcoming a range of 'strangers' into the Kingdom of God. (Luke 15:1-3.) We know that much of Jesus' ministry was spent eating and drinking with those deemed in the society of his time to be outcasts. McGovern explains that 'Jesus turned upside down the social and economic framework of his time until both religious and civil authorities came to perceive him as a threat' (p77). Jesus challenged what was considered acceptable by his actions of healing on the Sabbath, eating with tax collectors and extending his friendship to prostitutes. She explains that Jesus' actions mirrored eschatologically a Kingdom where there would be no division, no discrimination and as Galatians tells us, no distinction would be made between male or female, rich and poor and so on (Gal. 3:28).

'Hospitality; in Greek is 'Philoxenia' and words that come from the 'xen' stem can mean 'foreign' or 'strange' but, interestingly, also 'guest'. McGovern explains,

'Love of the xenos or 'stranger' seems clearly to have been a central distinctive tenet of Jesus' message and perhaps one of the hardest for his disciples to understand. Philoxenia is an expression of hospitality communicated at its purest in the New Testament precisely where it overcomes or transcends a fundamental 'estrangement' or fear of the other. Hospitality in this radical sense expresses or performs a 'coming together', or a sharing between guest and host, in which mutual difference is confronted and affirmed rather than erased' (McGovern 2010, p. 76).

The concept of hospitality cannot be explored without recognising the need for boundaries or rules for both host and guest to ensure the avoidance of an abuse of hospitality, or to protect from those who seek to exploit it for the wrong reasons. An etiquette of hospitality should be understood where the behaviour expected of both host and guest is learned and accepted.

This understanding of hospitality and otherness relates directly to the pastoral response of the Church to children who identify as LGBT in Catholic schools and what should be taught in the Religious Education classrooms of which they are a part. What should be, and is, apparent in many Catholic schools globally is an unequivocal welcome of every human being, regardless of their differences or views, accepting them and treating them as being made in the Image and Likeness of God. The Bishop of San Diego, McElroy tells us that, 'the Gospel demands that LGBT Catholics must be genuinely loved and treasured in the life of the church' (Martin 2017).

In Scotland, the Director of the Scottish Catholic Education Service opens her staff development sessions with the question, 'Did you see on the news or in the paper that story about the Catholic school in Scotland discriminating against a child identifying as LGBT?' When the answer is 'NO' she responds, 'That is because there is no story'. It is claimed that Catholic schools in Scotland, are places of inclusion and equality regardless of children's backgrounds, how they see themselves and how they identify. 


\section{Part 3: Supporting the Catholic teacher}

\subsection{We must lead as Jesus did, first with welcome, not condemnation. (Martin, 2017:169)}

James Martin's publication 'Building Bridges' received significant reaction from within the Church ranging from Cardinals endorsing his work and acclaiming him as one of the 'Church's foremost evangelizers' to others unleashing what Martin describes as a 'virtual torrent of hate' (ibid:6). Such extreme positions are as a result of the tension existing between to what is being referred to here as the Church's 'moral stance' on this matter and its 'pastoral position'. This manifests itself on a daily basis in the Catholic school where children are navigating their way through life, growing and forming their unique identity in the context of a place of faith that exists within a powerful secular culture. Most days they encounter peers who identify as LGBT in their school and who are being taught alongside them in the Religious Education classroom. The Church's moral position on many of the key topics pertaining to LGBT matters is expected to be conveyed in the RE classroom alongside the Catholic Social teaching principle of the life and dignity of each human being.

Drawing on earlier observations a number of key points will now be made:

1. Religious Education teachers, and indeed all teachers in the Catholic school, require to consider not only the language they choose to use in the classroom but how it is used. Pope Francis encourages caution of putting adjectives first and teachers should consider this in their everyday conversations. The point here is that it doesn't matter how someone identifies, educators are required to think about how they frame lessons and how they are leading discussions. Children are children, people are people. The key focus should be to recognise all as being made in the image and likeness of God, having an equal and valid contribution to make to this world and whose unique gifts contribute to building the Church in a special way. Reflecting on the ethic of hospitality, nobody should be made to feel 'less honourable' than another. Recognising and embracing 'otherness' can only contribute positively to our own understanding of ourselves and our unique contribution to the common good.

2. A fundamental position for teachers of Religious Education should be that any learning and teaching that happens in the classroom looks at the identity of individuals holistically avoiding compartmentalisation. Catholic educators are required to recognise that by accompanying young people as they grow and develop they should be encouraging them to understand that there is a range of characteristics that contribute to an individual's identity-race, ethnicity, religion, gender, sexual orientation, socioeconomic status and when teaching children we should be encouraging them to consider how all of these contribute to who they and others are, rather than just one or two. By rooting our work in Catholic Social Teaching and an understanding of Christian anthropology, we encourage children and young people to consider the uniqueness of the person, the differences we have, and the growth and learning that occurs when we welcome and encounter the 'other'. Teachers should support them as they consider this, encouraging them to reflect on why society identifies certain characteristics as being more vulnerable than others and what the Christian response to this is.

3. Pope Francis encourages educators to reflect on the 'task of the ears'. Martin echoes this by suggesting that for any learning to take place we need to listen. 'For the Church 
to exercise compassion, we need to listen. And when we listen, we will learn, we will be challenged and we will be inspired' (Martin 2017, p. 53). A true Christian ethic of hospitality relies on listening in order to dialogue. In this LGBT context, Catholic religious educators should not be fearful of young people listening to the perspectives of LGBT people. But young people in the Catholic school context should also be listening to the Church's perspective: they should know the person of Jesus, they should be knowledgeable and have a good understanding of Christian anthropology so that they have a solid basis upon which to form their own opinions. Perhaps we need to look again at our curriculum to establish if we provide for this depth of understanding of what the Church teaches to ensure that we are confident that our children can arrive at informed opinions.

4. The interest in Christian hospitality has returned as a result of globalization where 'otherness' challenges us daily. In the past this was as a result of ethnicity, religion and race but we now face a much more striated society where people are exerting their identity along multiple axes. There is a need to apply the language of Christian hospitality in our Catholic schools, but that requires everyone to understand it. A Christian understanding of hospitality should, therefore, feature prominently in our RE curriculums and Religious Education should be the driving force for informing the work of our school pastoral teams, through research and philosophical reflection in the field.

The concept of hospitality in the LGBT context could be challenged and others have suggested it be replaced with the New Testament's ethic of 'love' and unconditional acceptance. While this is attractive, it is recognised that there are features of LGBT lifestyle that unsettle Catholic belief and so there is a tension or estrangement that we have to face up to. We have to find an ethic that is viable where we do not pretend that there is no issue or difference. This paper then has argued that an ethic of Christian Hospitality is more granular, nuanced and recognises that there are points of difference and separation as well as solidarity.

Open Access This article is licensed under a Creative Commons Attribution 4.0 International License, which permits use, sharing, adaptation, distribution and reproduction in any medium or format, as long as you give appropriate credit to the original author(s) and the source, provide a link to the Creative Commons licence, and indicate if changes were made. The images or other third party material in this article are included in the article's Creative Commons licence, unless indicated otherwise in a credit line to the material. If material is not included in the article's Creative Commons licence and your intended use is not permitted by statutory regulation or exceeds the permitted use, you will need to obtain permission directly from the copyright holder. To view a copy of this licence, visit http://creativecommons.org/licenses/by/4.0/.

\section{References}

Ayoub, P. (2016). When states come out: Europe's sexual minorities and the politics of visibility. Cambridge, U.K.: Cambridge University Press.

Bruce, S. (2001). Catholic Schools in Scotland: a rejoinder to Conroy. Oxford Review of Education, 29(2), 269-277.

Catholic News Agency (2018) https://www.catholicnewsagency.com/news/cardinal-tobin-catechismlanguage-very-unfortunate-on-homosexuality-45966 (last accessed 20/1/19)

Coll, R (2009) Nemo dat quod non habet: authentic and authoritative Catholic teacher. PHD thesis, University of Glasgow.

Congregation for Catholic Education (2018) Male and Female He Created Them. Towards a path of dialogue on the question of gender theory in education. Vatican. 2019. 
Conroy, J. C. (2001). A Very Scottish Affair: Catholic education and the State. Oxford Review of Education, 27(4), 543-558.

Education Scotland (2017) Equality Strategy https://education.gov.scot/media/zk0f2nsn/equality-strat egy2017-19.pdf (Last accessed 8 August 2020)

Ghosh, A. (2020). The Global LGBT Workplace Equality Movement. In N. A. Naples (Ed.), Companion to Sexuality Studies. Sussex: Wiley.

Hacker, P. M. S., \& Schulte, J. (1953). Philosophical Investigations by Ludwig Wittgenstein. Sussex: Wiley.

Hutching, K., \& Fisher, E. (2019). Introduction to the special issue: The challenges and opportunities of including the community in Catholic education. Journal of Catholic Education, 22, 1-13.

Mannarini, T., Giuseppe, A. V., \& Salvatore, S. (2020). Media and Social Representations of Otherness:Psycho-Social-Cultural Implications. NJ: Springer International.

Martin, J. (2017). Building Bridges. New York: Harper Collins.

McGovern, D. (2010). Hospitality to the 'Other' in Faith-Based Schools. Unpublished thesis, University of Glasgow.

McKinney, S. J. (2008). Catholic schools in Scotland and divisiveness. Journal of Beliefs \& Values, 29(2), 173-184.

McKinney, S. J. (2015). Ricerche di Pedagogia e Didattica. Journal of Theories and Research in Education Special Issue Religion, Conflict and Education, 10(1), 13-45.

Office for National Statistics (2019) Sexual Orientation in UK https://www.ons.gov.uk/peoplepopulatio nandcommunity/culturalidentity/sexuality/bulletins/sexualidentityuk/2018 (Last accessed 8 August 2020)

Page, D (2019) Europe's LGBT Movement. Oxford Research Encyclopaedias.

Piquemal, N., Misir, D., \& Heringer, R. (2019). Responding to racial incivility in classrooms: Hospitality and responsibility. Journal of Global Education and Research, 3(2), 181-192. https://doi. org/10.5038/2577-509X.3.2.1081.

Pope Francis, Address to the Italian Catholic Primary School Teachers Association, (5 January 2018.)

Razu, J. M. (2019). Migrants and refugees approached from an ethic of hospitality. Journal of Asian mission, 20(1), 49-60.

Scottish Catholic Education Service (2018) Equality and Inclusion Learning and Teaching (https://sces.org. uk/equality-learning-and-teaching/ (Last accessed 8 August 2020)

Siegel, S. (2019). The Political Economy of LGBT Rights. In S. Siegel (Ed.), Oxford Research Encyclopedia of Politics. England: Oxford University Press.

Tadlock, B., \& Glick, C. (2019). North American and Australian LGBT Movement and Interest Groups. In B. Tadlock \& C. Glick (Eds.), Oxford Research Encyclopedia of Politics. England: Oxford University Press.

The Scottish Government (4 June, 2018) Cardinal Winning Lecture address given by First Minister, Nicola Sturgeon https://www.gov.scot/publications/cardinal-winning-lecture/ (Last accessed: 8 August 2020)

Publisher's Note Springer Nature remains neutral with regard to jurisdictional claims in published maps and institutional affiliations. 